\title{
COVID-19 Enfeksiyonu Geçiren ve Geçirmeyen Sağlık Çalışanlarında İki Doz İnaktive SARS-CoV-2 Aşısı Sonrası Antikor Yanıtı: Prospektif Gözlemsel Çalışma
}

\section{Antibody Response After Two Doses of Inactivated SARS-CoV-2 Vaccine in Healthcare Workers with and without Previous COVID-19 Infection: A Prospective Observational Study}

\author{
Didem ÖZGÜR'(ID), Emin Ediz TÜTÜNCÜ²(ID) \\ ${ }^{1}$ Kafkas Üniversitesi Tıp Fakültesi, Tıbbi Mikrobiyoloji Anabilim Dalı, Kars. \\ ${ }^{1}$ Kafkas University Faculty of Medicine, Department of Medical Microbiology, Kars, Turkey. \\ ${ }^{2}$ Kafkas Üniversitesi Tıp Fakültesi, Enfeksiyon Hastalıkları ve Klinik Mikrobiyoloji Anabilim Dalı, Kars. \\ ${ }^{2}$ Kafkas University Faculty of Medicine, Department of Infectious Diseases and Clinical Microbiology, Kars, Turkey.
}

\begin{abstract}
*Bu çalışma, Kafkas Üniversitesi Bilimsel Araştırma Projeleri Birimi (Proje No: 2021-TS-19) tarafından desteklenmiştir. Bu çalışmaya ait veriler 9. Türkiye EKMUD Uluslararası Bilimsel Platformu (20-23 Mayıs 2021, Online Kongre)'nda sözlü bildiri olarak sunulmuştur.
\end{abstract}

Makale Atıfı: Özgür D, Tütüncü EE. COVID-19 enfeksiyonu geçiren ve geçirmeyen sağlık çalısanlarında iki doz inaktive SARSCoV-2 aşısı sonrası antikor yanıtı: Prospektif gözlemsel çalışma. Mikrobiyol Bul 2022;56(1):36-48.

\section{ÖZ}

Bu çalışmada, koronavirüs hastalığı 2019 (COVID-19) açısından risk grubunda yer alan sağlık çalışanlarında, inaktif şiddetli akut solunum yolu sendromu koronavirüs-2 (SARS-CoV-2) aşısı sonrası oluşan anti-S1 IgG yanıtının ve bu yanıtı etkileyen faktörlerin araştııııması amaçlanmıştır. Çalışmaya, Kafkas Üniversitesi Tıp Fakültesi, Sağlık Araştırma ve Uygulama Merkezinde görev yapan, daha önce COVID-19 enfeksiyonu geçiren 82 ve geçirmeyen 194 kişi olmak üzere toplam 276 sağlık çalışanı dahil edilmiştir. illk ve ikinci doz aşı uygulamasından 28 gün sonra alınan serum örneklerinde, humoral immün yanıın kantitatif olarak belirlenmesi için SARS-CoV-2 S proteininin reseptör bağlama alanını içeren rekombinant S1 antijeni ile kaplı, Anti-SARS-CoV-2 QuantiVac ELISA IgG (Euroimmun, Lubeck, Almanya) kiti kullanılmıstır. COVID-19 enfeksiyonu geçirmeyen 194 sağlık çalışanının ilk ve ikinci doz aşı uygulamasından 28 gün sonra sırasıyla antikor yanıtlarının \%27.2 ve \%98.5; ortalama antikor düzeylerinin $19.72 \pm 38.73$ bağlayıcı antikor ünite (BAU) ve $222.09 \pm 119.18$ BAU olduğu belirlenmiştir. COVID-19 enfeksiyonu geçiren 82 sağlık çalışanının ise ilk ve ikinci doz aşı uygulamasından 28 gün sonra ortalama antikor düzeylerinin sırasıyla $268.27 \pm 112.91$ BAU ve $309.45 \pm 112.75$ BAU olduğu ve ilk doz aşı uygulamasından sonra \%100 antikor yanıtı sağlandığı tespit edilmiştir. Her iki grupta da, ilk ve ikinci doz aşı uygulamasından sonra saptanan antikor düzeyleri arasında istatistiksel olarak anlamlı bir fark olduğu gözlemlenmiştir ( $p<$ 0.001). COVID-19 enfeksiyonu geçiren sağlık çalışanlarının ilk doz aşı uygulamasından sonra oluşan ortalama antikor düzeyinin, naif bireylerde ikinci doz aşı uygulamasından sonra oluşan ortalama antikor 
düzeyinden istatistiksel olarak daha yüksek olduğu saptanmıştır $(p=0.003)$. COVID-19 enfeksiyonunu son üç ay içerisinde ve üç aydan daha önce geçiren bireyler arasında ilk (sırasıyla, 269.10 1117.24 BAU ve $266.59 \pm 105.65 \mathrm{BAU}$ ) ve ikinci (sırasıyla, $309.98 \pm 113.17$ ve $308.36 \pm 114.04 \mathrm{BAU}$ ) doz sonrası ortalama antikor düzeyleri bakımından anlamlı bir fark olmadığı tespit edilmiştir (sırasıyla, $p=0.925$ ve $p=0.951$ ). COVID-19 enfeksiyonu geçirmeyen sağlık çalışanlarında ikinci doz aşı uygulamasından sonra en yüksek antikor düzeyleri 19-30 yaş grubunda (251.50 $\pm 119.81 \mathrm{BAU})$, kadınlarda (249.03 $\pm 118.57 \mathrm{BAU})$, vücut kitle indeksi $(\mathrm{VKI})<20 \mathrm{~kg} / \mathrm{m}^{2}$ grubunda olan $(267.08 \pm 137.51 \mathrm{BAU})$ ve sigara kullanmayanlarda (237.85 $\pm 124.83 \mathrm{BAU}$ ) saptanmıştır. Yaş, cinsiyet, VKi ve sigara kullanımı ile aşı yanıtı arasında istatistiksel olarak anlamlı fark olduğu tespit edilmiştir (sırasıyla, $p=0.003, p=0.005, p=0.008$ ve $p=0.036$ ). Illk ve ikinci doz aşı sonrası sağlık çalışanlarının sırasıyla \%76.1 ve \%73.9'unda aşı sonrası istenmeyen etki (ASiE) gözlenmemiştir. COVID-19 enfeksiyonu geçiren ve geçirmeyen bireylerde, ilk ve ikinci doz sonrasında ASiE sıklığında artış saptanmamıştır $(p=0.46$ ve $p=0.43)$. Bu çalışmada, COVID-19 enfeksiyonu geçiren sağlık çalışanlarında ilk doz aşılamadan sonra elde edilen ortalama antikor düzeyinin, COVID-19 enfeksiyonu geçirmeyen bireylerde ikinci doz aşılamadan sonra elde edilen ortalama antikor düzeyinden daha yüksek olduğu saptanmıştır. COVID-19 enfeksiyonundan korunmada, antikor düzeyleri ve koruyuculuk süreleriyle ilgili ileriye dönük klinik çalışmalara gereksinim olduğunu düşünmekteyiz.

Anahtar kelimeler: COVID-19; inaktive SARS-CoV-2 aşısı; anti-s1 IgG yanıtı; spike protein.

\section{ABSTRACT}

In this study, we aimed to investigate the anti-S1 IgG response that occurs after inactivated severe acute respiratory syndrome coronavirus-2 (SARS-CoV-2) vaccine and the factors affecting this response in healthcare workers (HCWs) who are in the risk group for coronavirus disease 2019 (COVID-19). A total of 276 HCWs, of whom 82 previously exposed to COVID-19 infection and 194 naive who are working in Kafkas University Faculty of Medicine, Health Research and Application Center were included in this study. Anti-SARS-CoV-2 QuantiVac ELISA IgG (Euroimmun, Lubeck, Germany) kit, coated with recombinant S1 antigen including the receptor binding domain of the SARS-CoV-2 S protein was used for quantitative determination of the humoral immune response in serum samples 28 days after the first and second dose of vaccination. The antibody responses and the mean antibody levels of 194 naive HCWs 28 days after the first and second doses of vaccine were determined to be $27.2 \%, 98.5 \%$ and $19.72 \pm$ $38.73 \mathrm{BAU}, 222.09 \pm 119.18$ binding antibody unit (BAU), respectively. The mean antibody levels of 82 HCWs previously exposed to COVID-19 infection 28 days after the first and second doses of vaccine were $268.27 \pm 112.91 \mathrm{BAU}$ and $309.45 \pm 112.75 \mathrm{BAU}$, respectively. The antibody response reached $100 \%$ after the first dose of vaccination. A statistically significant difference was observed between the antibody levels after the first and second doses of vaccine in both groups $(p<0.001)$. It was determined that the mean antibody level formed after the first dose of vaccine administration of HCWs who had COVID-19 infection was statistically higher than the mean antibody level formed after the second dose of vaccine in naive individuals $(p=0.003)$. There was no significant difference in mean antibody levels after the first $(269.10 \pm 117.24 \mathrm{BAU}$ and $266.59 \pm 105.65 \mathrm{BAU}$, respectively) and second doses (309.98 \pm 113.17 and $308.36 \pm 114.04 \mathrm{BAU}$, respectively) between individuals previously exposed to COVID-19 infection in the last three months and more than three months $(p=0.925$ and $p=0.951$, respectively). The highest antibody levels were detected in the 19-30 age group (251.50 $\pm 119.81 \mathrm{BAU})$, women (249.03 \pm 118.57 $\mathrm{BAU})$, body mass index $(\mathrm{BMI})<20 \mathrm{~kg} / \mathrm{m}^{2}$ group $(267.08 \pm 137.51)$ and non-smokers $(237.85 \pm 124.83$ $\mathrm{BAU})$ in naive HCWs after the second dose of vaccination. A statistically significant difference was found between age, gender, $B M I$, smoking and vaccine response $(p=0.003, p=0.005, p=0.008$ and $p=0.036$, respectively). The post-vaccination adverse effects after the first and second doses of vaccination were not observed in $76.1 \%$ and $73.9 \%$ of HCWs, respectively. There was no increase in the frequency of post-vaccination adverse events after the first and second doses in individuals previously exposed to $\mathrm{CO}$ VID-19 infection and naive persons ( $p=0.46$ and $p=0.43$, respectively). It was determined that the mean antibody level after the first dose of vaccination in HCWs previously exposed to COVID-19 infection was higher than naive individuals after the second dose vaccination. Prospective clinical studies on antibody levels and their duration of protection are needed for the prevention of COVID-19 infection.

Keywords: COVID-19; inactivated SARS-CoV-2 vaccine; anti-s1 IgG response; spike protein. 


\section{Gíriş}

Çin'in Wuhan kentinde Aralık 2019'da ortaya çıkan ve yeni bir koronavirüs olan şiddetli akut solunum sendromu koronavirüs-2 (SARS-CoV-2), 11 Mart 2020'de Dünya Sağlık Örgütü (DSÖ) tarafından pandemi olarak ilan edilen koronavirüs hastalığı 2019 (COVID-19)'un etiyolojik ajanıdır ${ }^{1,2}$. DSÖ verilerine göre, Eylül 2021 sonu itibarıyla dünya çapında dört buçuk milyondan fazla ölümle birlikte 230 milyondan fazla doğrulanmış COVID-19 olgusu bildirilmiştir ${ }^{3}$.

SARS-CoV-2'ye karşı humoral immün yanıtta, esas olarak spike ( $S$ ) glikoproteinini ve nükleokapsid $(\mathrm{N})$ proteinini hedef alan antikorlar rol oynamaktadır. Bu tür antikorlar, anjiyotensin dönüştürücü enzim 2 (ACE2)'yi eksprese eden insan hücrelerinin ve dokularının viral enfeksiyonunu nötralize eder ${ }^{4}$. S glikoproteini 180 kDa ağırığında olup, S1 ve S2 olmak üzere iki alt birimden oluşur ${ }^{5}$. S1 alt birimi, ACE2 reseptör aracılığıyla virüsün konak hücreye girişinden sorumlu reseptör bağlama alanını [receptor-binding domain (RBD)] içermesi, nötralizan antikor indüksiyon kapasitesi ve türe özgü antijenik özgüllüğü nedeniyle, SARS-CoV-2'yi nötralize eden antikorlar için en iyi immünolojik hedeflerden biridir $^{5-7}$. Nötralizan antikorlar; virüsün ACE2'ye verimli bir şekilde bağlanmasını ve hedef hücre ile etkileşime girmesi için gereken konformasyonel değişikliği önleyerek viral klirenste önemli rol oynamaktadır ${ }^{8,9}$.

Pandemi süresince fiziksel mesafenin korunması, karantina ve izolasyon önlemleri morbidite ve mortalite artışının kısmen önüne geçmişse de toplumda bu yeni etkene karşı bağışıklığın olmaması SARS-CoV-2 enfeksiyonunun kontrol altına alınmasını zorlaştırmaktadır. Pandeminin kontrol altına alınması için aşı geliştirme çabaları erken dönemde başlamış ve günümüzde mRNA aşıları, adenoviral vektör bazlı aşılar ve inaktif virüs aşıları gibi farklı prensiplere dayanan aşılar faz çalışmaları sonrasında kullanıma girmiştir ${ }^{9}, 10$. SARS-CoV-2 aşıları, hücreleri enfekte etmede önemli rol oynayan virüsün S proteini ya da RBD'ye karşı humoral ve hücresel bağışıklık yanıtı ve nötralizan antikorları indükleme stratejisine dayanmaktadır ${ }^{9}, 11$.

CoronaVac, Sinovac Life Sciences Co., Ltd. (Beijing, Çin) tarafından geliştirilen inaktif edilmiş bir SARS-CoV-2 aşıııdır. CoronaVac aşısının, rodentler ve insan olmayan primatlar gibi farklı hayvan modellerinde güvenilir ve immünojenik olduğu gösterildikten sonra, faz $1 / 2$ çalışmaları Çin'de başlatılmış, aşının nötralize edici antikorları indüklediğini gösterilmiştir $^{10,12,13}$. Faz 3 çalışmalarının ardından, inaktif SARS-CoV-2 aşısı 14 Ocak 2021 tarihinden itibaren, ülkemizde başta sağlık çalışanları olmak üzere ülke genelinde uygulanmaya başlanmıştır. 29 Eylül 2021 tarihi itibariyle ülkemizde 44059772 kişi iki doz SARS-CoV-2 aşısı ile aşılanmışıır ${ }^{14}$.

Bu çalışmada, COVID-19 açısından risk grubunda yer alan sağlık çalışanlarında iki doz inaktif SARS-CoV-2 aşısı (CoronaVac) uygulanması sonrası oluşan antikor yanıtlarının belirlenmesi ile bu yanıtı etkileyen faktörlerin ve COVID-19 enfeksiyonu geçirmiş bireylerdeki aşı yanıtının değerlendirilmesi amaçlanmıştır. 


\section{GEREÇ ve YÖNTEM}

Bu çalışma, TC Sağlık Bakanlığı COVID-19 Bilimsel Araştırma Değerlendirme Komisyonu onayı (Tarih: 12.02.2021 ve Karar No: 2021-02-10T16-23-51) ve Kafkas Üniversitesi Klinik Araştırmalar Etik Kurulu onayı (Tarih: 11.03.2021 ve Karar No: 2021/29) alınarak gerçekleştirildi.

\section{Çalışma Popülasyonu ve Örnekler}

Çalışmaya, Kafkas Üniversitesi Tıp Fakültesi, Sağlık Araştırma ve Uygulama Merkezinde görev yapan 287 sağlık çalışanı, bilgilendirilmiş onam alınarak dahil edildi. Sağlık çalışanlarından kan örnekleri, birinci ve ikinci doz aşı uygulamasından 28 gün sonra alındı. İkinci doz aşı uygulanmasından 28 gün sonra kan örneği alınamayan 11 kişi, çalışma kapsamı dışında bırakıldı.

SARS-CoV-2 antikor yanıtını etkileyebilecek faktörlerin belirlenmesi amacıyla yaş, cinsiyet, boy, kilo, sigara kullanımı ve COVID-19 enfeksiyonu geçirme durumu kayıt altına alındı. ASIE varlığı, aşı uygulamasından yedi gün sonra tüm katılımcılarda sorgulandı.

Çalışmaya dahil edilen sağlık çalışanlarından 4-5 ml kan örneği, etilendiamin tetraasetik asit (EDTA)'li tüplere alındı ve 3500 rpm'de 10 dakika santrifüj edilerek serum örnekleri ayrıldı. Elde edilen serum örnekleri, çalışmaya alınana kadar $-80^{\circ} \mathrm{C}^{\prime}$ de muhafaza edildi.

\section{Enzime Bağlı İmmünosorbent Deneyi (ELISA) Testi}

SARS-CoV-2 IgG sınıfı antikorların kantitatif olarak belirlenmesi için, SARS-CoV-2 S proteininin RBD'yi de içeren rekombinant S1 antijeni ile kaplı, Anti-SARS-CoV-2 QuantiVac ELISA IgG (Euroimmun, Lubeck, Almanya) kiti kullanıldı. Serum örnekleri, numune tamponu ile 1:101 oranında seyreltildi ve üretici firmanın talimatları doğrultusunda test edildi. Çalışma sonunda her bir kuyucuğun absorbansı $450 \mathrm{~nm}$ 'de spektrofotometrik olarak belirlendi. Sonuçlar, konsantrasyonları 1-120 relatif ünite (RU/ml) arasında değişen altı adet kalibratör için ölçülen optik dansite değerlerine karşılık gelen birimlere noktasal kalibrasyon eğrisi çizilmesiyle hesaplandı. Doğrusal regresyon ile antikor konsantrasyonları RU/ml cinsinden belirlendi. RU/ml cinsinden elde edilen kantitatif sonuçlar, DSÖ'nün spesifikasyonlarına uygun olarak 3.2 ile çarpılarak BAU/ml'ye çevrildi. Antikor konsantrasyonu $<25.6 \mathrm{BAU} / \mathrm{ml}$ olan örnekler negatif, $\geq 25.6 \mathrm{BAU} / \mathrm{ml} \leq 35.2 \mathrm{BAU} / \mathrm{ml}$ olan örnekler sınırda pozitif ve $\geq 35.2 \mathrm{BAU} / \mathrm{ml}$ olanlar ise pozitif olarak değerlendirildi. Numunelerin optik dansitesi kalibratör $1(120 \mathrm{RU} / \mathrm{ml})$ 'in üzerindeyse, serum örnekleri 1/400 oranında seyreltilerek tekrar çalışmaya alındı ve elde edilen sonuçlar dört ile çarpıldı.

\section{İstatistiksel Analiz}

İstatistiksel analizlerde; tanımlayıcı istatistikler, sürekli değişkenler için ortalama \pm standart sapma (SD) şeklinde verilirken, kategorik değişkenler için yüzde ve frekanslar kullanıldı. Normallik varsayımı Shapiro-Wilks ve Kolmogorov-Smirnov testleri ile gerçekleştirildi. Bağımsız yapıdaki değiş̧kenlerin karşılaştırılmasında independent t test; bağımlı yapıdaki değişkenlerin karşılaştırılmasında paired sample t test kullanıldı. İkiden fazla grup olduğu 
durumlarda tek yönlü varyans analizi ve bonferroni post-hoc analizleri uygulandı. Tüm analizlerde istatistiksel olarak anlamlılık derecesi ( $p$ değeri) 0.05 olarak belirlendi ve analizler R version 3.6.0 programı ile yapıldı.

\section{BULGULAR}

Çalışmaya alınan 276 sağlık çalışanının 150 (\%54.3)'si kadın, 126 (\%45.7)'sı erkek olup, yaş ortalaması $33.62 \pm 10.31$ (yaş aralığı= 19-68) yıl olarak tespit edilmiştir. Daha önceden gerçek zamanlı revers transkriptaz polimeraz zincir reaksiyonu (rRT-PCR) ile doğrulanmış COVID-19 enfeksiyonu geçirme durumu \%29.7 ( $n=82$ ) olarak saptanmıştır. İnaktif SARS-CoV-2 aşısına karşı antikor yanıtını etkileyen faktörlerin belirlenmesi amacıyla toplanan verilere göre, COVID-19 enfeksiyonu geçiren ve geçirmeyen gruplar arasında yaş, cinsiyet ve VKi bakımından istatistiksel olarak anlamlı bir fark olmadığı görülmüştür (Tablo I) (sırasıyla, $p=0.12, p=0.49$ ve $p=0.13$ ).

COVID-19 enfeksiyonu geçirmeyen 194 (\%70.3) sağlık çalışanının ilk ve ikinci doz aşı uygulamasından 28 gün sonra sırasıyla antikor yanıtlarının \%27.3 $(n=53)$ ve \%98.5 $(\mathrm{n}=191)$; ortalama antikor düzeylerinin 19.72 $\pm 38.73 \mathrm{BAU}$ (\%95 GA, 14.27-25.17) ve $222.09 \pm 119.18$ BAU (\%95 GA, 205.32-238.86) olduğu belirlenmiştir. Ortalama $84.6 \pm$

\begin{tabular}{|c|c|c|c|c|}
\hline & $\begin{array}{c}\text { Toplam }(n=276) \\
n(\%)\end{array}$ & $\begin{array}{c}\text { COVID-19 } \\
\text { enfeksiyonu } \\
\text { geçirmeyen bireyler } \\
(n=194) n(\%)\end{array}$ & $\begin{array}{c}\text { COVID-19 } \\
\text { enfeksiyonu } \\
\text { geçiren bireyler } \\
(n=82) n(\%)\end{array}$ & $\mathbf{p}$ \\
\hline \multicolumn{5}{|l|}{ Yaş, yıl } \\
\hline Yaş ortalaması \pm SD (Aralık) & $33.62 \pm 10.31(19-68)$ & $34.2 \pm 10.75(19-64)$ & $32.23 \pm 9.1(22-68)$ & \multirow{4}{*}{0.12} \\
\hline $19-30$ & $133(\% 48.2)$ & $88(\% 45.4)$ & $45(\% 54.9)$ & \\
\hline $31-40$ & $81(\% 29.3)$ & $56(\% 28.9)$ & $25(\% 30.5)$ & \\
\hline$\geq 41$ & $62(\% 22.5)$ & $50(\% 25.7)$ & $12(\% 14.6)$ & \\
\hline \multicolumn{5}{|l|}{ Cinsiyet } \\
\hline Kadın & $150(\% 54.3)$ & $108(\% 55.7)$ & $42(\% 51.2)$ & \multirow[t]{2}{*}{0.49} \\
\hline Erkek & $126(\% 45.7)$ & $86(\% 44.3)$ & $40(\% 48.8)$ & \\
\hline \multicolumn{5}{|l|}{ VKi $\left(\mathrm{kg} / \mathrm{m}^{2}\right)$} \\
\hline VKI ortalaması \pm SD & $24.97 \pm 4.04$ & $24.73 \pm 4.05$ & $25.53 \pm 3.98$ & \multirow{4}{*}{0.13} \\
\hline$<20$ & $31(\% 11.3)$ & $24(\% 12.4)$ & $7(\% 8.5)$ & \\
\hline $20-25$ & $121(\% 43.8)$ & $90(\% 46.4)$ & $31(\% 37.8)$ & \\
\hline 25 & $124(\% 44.9)$ & $80(\% 41.2)$ & $44(\% 53.7)$ & \\
\hline \multicolumn{5}{|l|}{ Sigara kullanımı } \\
\hline Yok & $168(\% 60.9)$ & $108(\% 55.7)$ & $60(\% 73.2)$ & \multirow[t]{2}{*}{0.006} \\
\hline Var & $108(\% 39.1)$ & $86(\% 44.3)$ & $22(\% 26.8)$ & \\
\hline \multicolumn{5}{|l|}{ İstenmeyen etki } \\
\hline 1. doz aşılama sonrası & $66(\% 23.9)$ & $44(\% 22.7)$ & $22(\% 26.8)$ & 0.46 \\
\hline 2. doz aşılama sonrası & $72(\% 26.1)$ & $48(\% 24.7)$ & $24(\% 29.2)$ & 0.43 \\
\hline
\end{tabular}




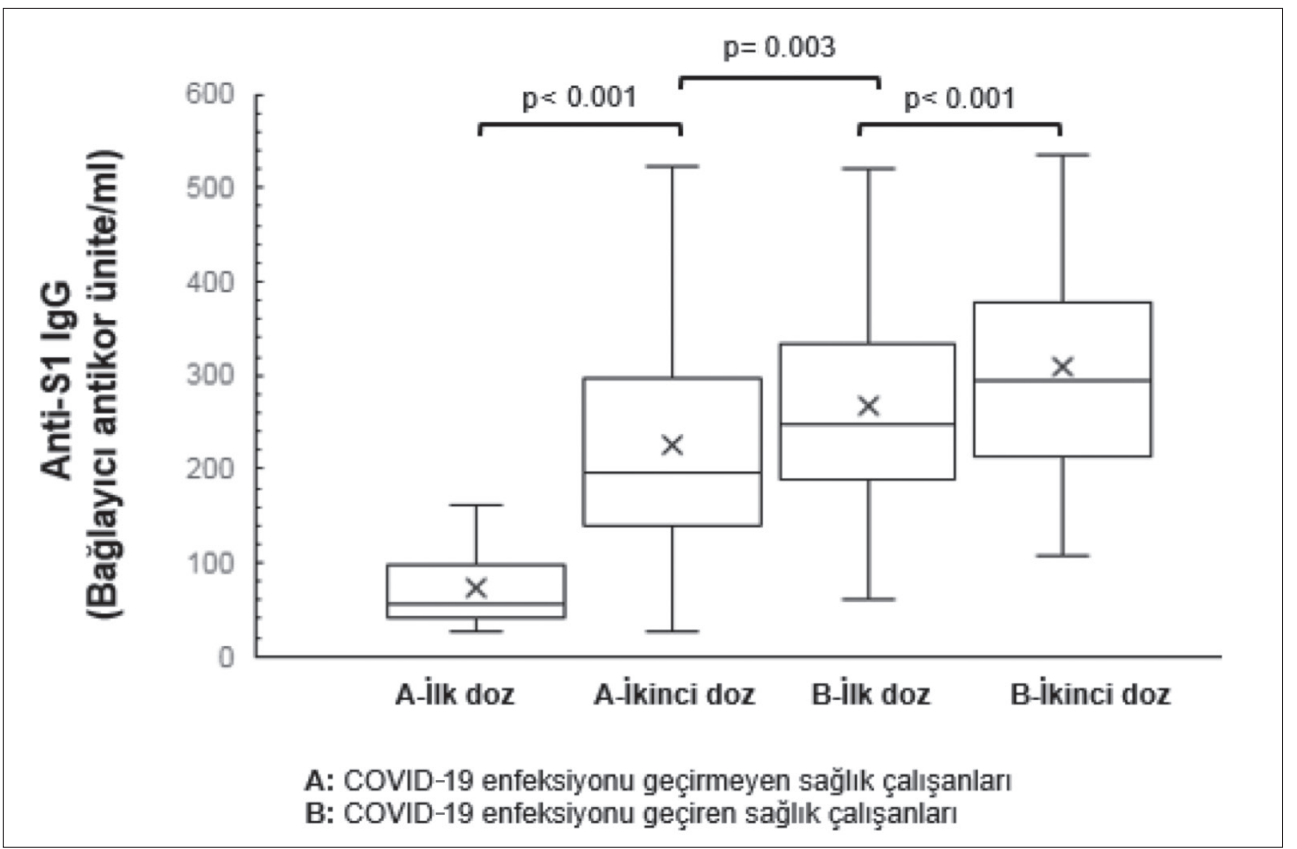

Şekil 1. İlk ve ikinci doz aşı uygulaması sonrası antikor yanıtı.

49.6 (gün= 12-268) gün önce COVID-19 enfeksiyonu geçiren 82 sağlık çalışanının ise ilk ve ikinci doz aşı uygulamasından 28 gün sonra ortalama antikor düzeylerinin sırasıyla 268.27 \pm 112.91 BAU (\%95 GA, 243.83-292.70) ve 309.45 \pm 112.75 BAU (\%95 GA, 285.05333.85) olduğu ve ilk doz aşı uygulamasından sonra \%100 antikor yanıtı sağlandığı tespit edilmiştir. Her iki grupta da, ilk ve ikinci doz aşı uygulamasından sonra saptanan antikor düzeyleri arasında istatistiksel olarak anlamlı bir fark olduğu gözlenmiştir (Şekil 1) ( $p<0.001$ ). Ayrıca COVID-19 enfeksiyonu geçiren sağlık çalışanlarının ilk doz aşı uygulamasından sonra oluşan ortalama antikor düzeyinin, COVID-19 enfeksiyonu geçirmeyen sağlık çalışanlarının ikinci doz aşı uygulamasından sonra oluşan ortalama antikor düzeyinden daha yüksek olduğu ve istatistiksel olarak anlamlı bir fark olduğu saptanmıştır $(p=0.003)$.

COVID-19 enfeksiyonu geçirmiş olan sağlık çalışanlarının \%32.9 (27/82)'unun son üç ay içerisinde, \%67.1 (55/82)'inin üç aydan daha önce COVID-19 enfeksiyonu geçirdiği tespit edilmiştir. COVID-19 enfeksiyonunu son üç ay içinde ve üç aydan daha önce geçiren sağlık çalışanları arasında ilk ve ikinci doz ortalama antikor yanıtları bakımından istatistiksel olarak anlamlı bir fark olmadığı tespit edilmiştir (sırasıyla $p=0.925$ ve $p=0.951$ ).

İkinci doz aşılama sonrası, COVID-19 enfeksiyonu geçirmeyen 19-30 yaş, 31-40 yaş ve $\geq 41$ yaş gruplarında yer alan sağlık çalışanlarının ortalama antikor düzeyleri sırasıyla $251.50 \pm 119.81 \mathrm{BAU}, 210.89 \pm 122.60 \mathrm{BAU}$ ve 182.86 \pm 101.59 BAU olarak saptanmıştır. Yaş ile ortalama antikor düzeyi arasında istatistiksel olarak anlamlı bir fark olduğu gözlenmiştir ( $p=0.003)$. Bu istatistiksel anlamlı farkın, 19-30 yaş ile $\geq 41$ yaş grupları arasında istatistiksel olarak anlamlı fark olmasından kaynaklandığı saptanmıştır $(p=0.01)$. Daha 
önce COVID-19 enfeksiyonu geçiren sağlık çalışanlarında ise yaş ile ortalama antikor düzeyi bakımından istatistiksel olarak anlamlı bir fark olmadığı tespit edilmiştir $(p=0.103)$.

COVID-19 enfeksiyonu geçirmeyen sağlık çalışanlarının 108 (\%55.7)'i kadın, 86 (\%44.3)'sı erkek olup, ikinci doz aşılama sonrası ortalama antikor düzeyleri sırasıyla $249.03 \pm 118.57$ BAU ve 200.63 \pm 115.77 BAU olarak belirlenmiştir. Cinsiyet ile aşı yanıtı arasında istatistiksel olarak anlamlı fark olduğu tespit edilmiştir ( $p=0.005)$. COVID-19 enfeksiyonu geçiren sağlık çalışanlarında ise, cinsiyet bakımından istatistiksel olarak anlamlı bir fark saptanmamıştır $(p=0.975)$.

VKi bakımından, COVID-19 enfeksiyonu geçiren ve geçirmeyen sağlık çalışanlarında en yüksek ortalama antikor düzeyleri sırasıyla $336.43 \pm 103.88$ BAU ile $20-25 \mathrm{~kg} / \mathrm{m}^{2}$ grubunda ve $267.08 \pm 137.51 \mathrm{BAU}$ ile $<20 \mathrm{~kg} / \mathrm{m}^{2}$ grubunda tespit edilmiştir. COVID-19 enfeksiyonu geçiren ve geçirmeyen sağlık çalışanlarında, antikor yanıtı ile VKi arasında istatistiksel olarak anlamlı bir fark olduğu saptanmıştır (sırasıyla, $p=0.049$ ve $p=0.008$ ).

COVID-19 enfeksiyonu geçiren ve geçirmeyen sağlık çalışanlarında sigara içenlerin ortalama antikor düzeyleri sırasıyla 256.83 \pm 88.09 BAU ve 202.29 \pm 109.19 BAU; sigara içmeyenlerin ise sırasıyla $328.74 \pm 115.24 \mathrm{BAU}$ ve $237.85 \pm 124.83 \mathrm{BAU}$ olarak belirlenmiştir. Her iki grupta da, sigara kullanımı ile antikor yanıtı arasında istatistiksel olarak anlamlı bir fark olduğu saptanmıştır (Tablo II) (sırasıyla $p<0.001$ ve $p=0.036$ ).

Hastaların ilk ve ikinci doz aşılanmaları sonrası sırasıyla \%23.9 $(n=66)^{\prime}$ unda ve \%26.1 $(n=72)^{\prime}$ inde ASIE gözlenmiştir. Tüm sağlık çalışanlarında ilk ve ikinci doz inaktif SARSCoV-2 aşı uygulaması sonrasında ASIE bakımından istatistiksel olarak anlamlı bir fark olmadığı görülmüştür ( $p=0.55)$. Buna ek olarak, COVID-19 enfeksiyonu geçiren ve geçirmeyen sağlık çalışanları arasında ilk ve ikinci doz sonrası ASiE bakımından istatistiksel olarak anlamlı bir fark olmadığı belirlenmiştir (sırasıyla $p=0.46$ ve $p=0.43$ ). Illk ve ikinci doz aşı uygulaması sonrası görülen ASiE dağılımı Şekil 2'de verilmiştir.

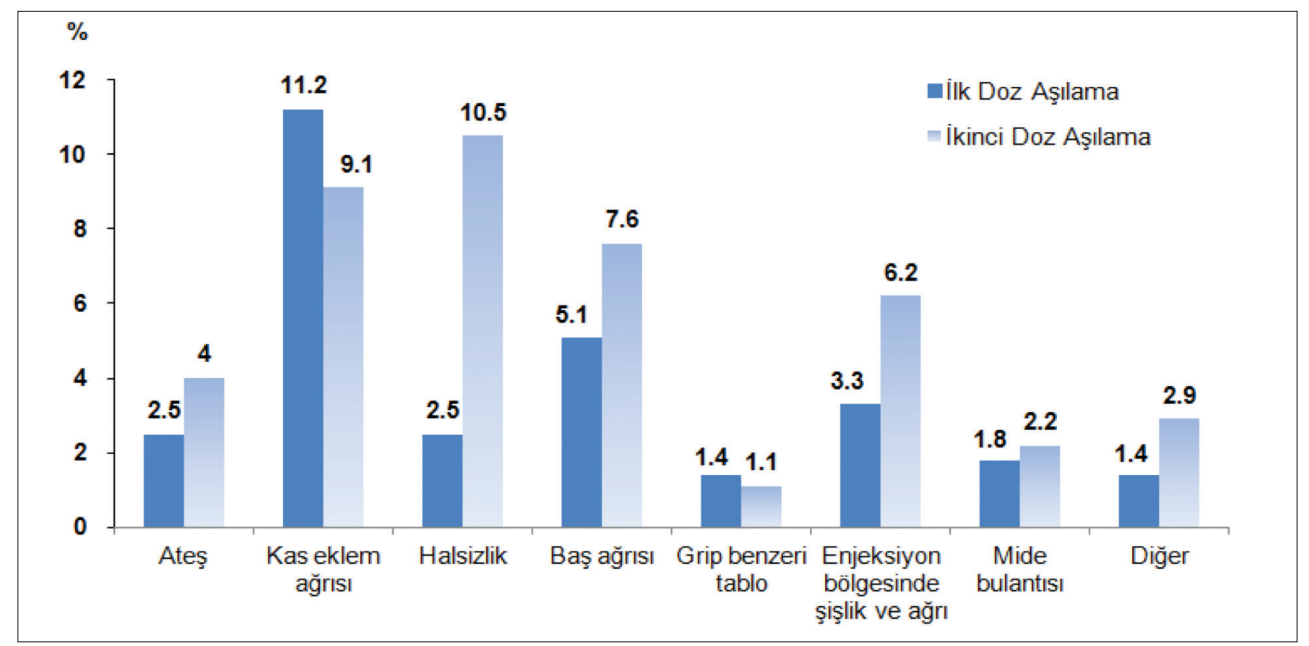

Şekil 2. Ilk ve ikinci doz aşı uygulaması sonrası görülen ASiE dağııımı (\%). 


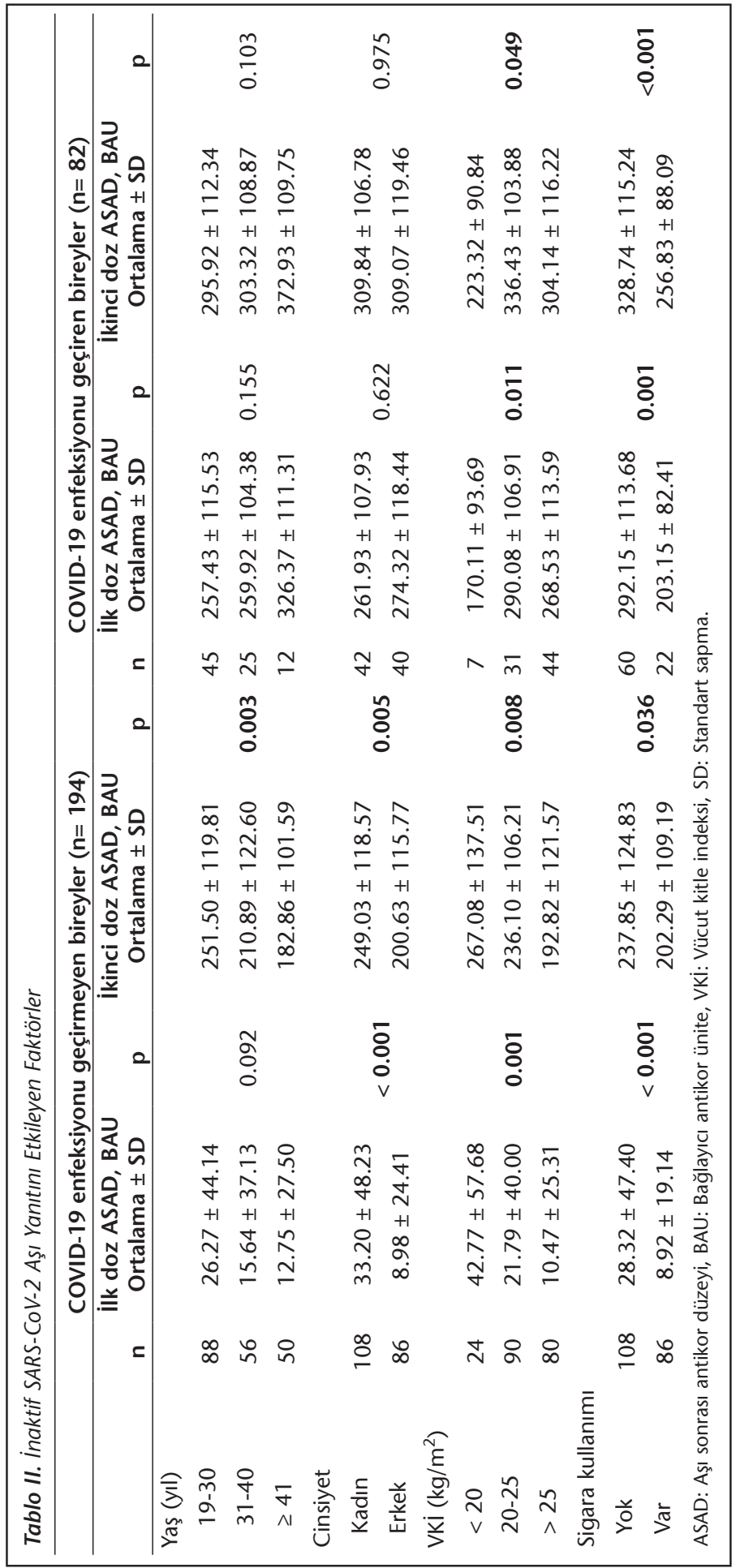




\section{TARTIŞMA}

COVID-19 pandemisinin yönetiminde aktif bağışıklamadan sonra özgül antikorların belirlenmesi, hem aşı geliştirme ve onay sürecinde hem de aşılanmış bireylerin takibinde önemli bir yer tutmaktadır ${ }^{15}$. Bu çalışmada, COVID-19 enfeksiyonu geçirmemiş sağlık çalışanlarında ilk ve ikinci doz inaktif SARS-CoV-2 aşı uygulamasından 28 gün sonra sırasıyla \%27.2 ve \%98.5; COVID-19 enfeksiyonu geçirmiş sağlık çalışanlarında ise ilk doz aşı uygulamasından sonra \%100 oranında anti-S1 IgG yanıtı sağlandığı tespit edilmiştir. Birinci doz aşı uygulaması sonrası saptanan antikor düzeyleri arasındaki fark (19.72 \pm 38.73 BAU'ya karşı $268.27 \pm 112.91$ BAU), COVID-19 enfeksiyonu geçiren bireylerin sekonder immün yanıta bağlı hızlı ve güçlü antikor yanıtı vermeleriyle izah edilebilir.

İnaktif SARS-CoV-2 aşısının Faz 1/2 klinik çalışmalarında 18-59 yaş grubunda, ikinci doz aşılama sonrası \%100 oranında anti-RBD IgG serokonversiyonu bildirilmiştir ${ }^{10}$. Dünyada kullanımda olan SARS-CoV-2 mRNA aşılarından BNT162b2/Pfizer-BioNTech'in \%92, 1273/Moderna'nın \%100; viral vektör aşılarından AstraZeneca'nın \%92.9; Sputnik V (rAd26-S ve rAd5-S)'in \%100; inaktif virüs aşılarından BBIBP-CorV/Sinopharm'ın \%96 ve $\% 100$ oranlarında antikor yanıtı sağladığı saptanmıştır ${ }^{16-20}$. SARS-CoV-2 aşılarının farklı düzeyde serokonversiyon sağlaması, aşı üretiminde kullanılan teknolojinin ve hedef antijenlerin antikor yanıtını etkilediğini göstermektedir.

Bu çalışmada COVID-19 enfeksiyonu geçiren sağlık çalışanlarında ilk doz aşılamadan sonra elde edilen ortalama antikor düzeyinin, COVID-19 enfeksiyonu geçirmeyen sağlık çalışanlarında ikinci doz aşılamadan sonra elde edilen ortalama antikor düzeyinden istatistiksel olarak anlamlı düzeyde daha yüksek olduğu saptanmıştır. COVID-19 enfeksiyonu geçiren bireylerde; aşı sonrası aktif olan bellek B hücrelerine bağlı gelişen sekonder immün yanıt, naif bireylere kıyasla daha yüksek antikor yanıtına yol açmaktadır. mRNA aşılarından BNT162b2/Pfizer-BioNTech ve 1273/Moderna'nın ve adenoviral vektör tabanlı Sputnik V (rAd26-S ve rAd5-S) aşısının çalışmamıza benzer biçimde, COVID-19 enfeksiyonu geçirmiş bireylerde sekonder immün yanıta bağlı hızlı ve yüksek humoral yanıt sağladığı ve tek doz aşı sonrası antikor düzeylerinin COVID-19 enfeksiyonu geçirmeyen bireylerin ikinci dozundan daha yüksek olduğu saptanmıştır ${ }^{16,21-24}$. Tek doz inaktif SARSCoV-2 aşısının da benzer şekilde, COVID-19 enfeksiyonu geçiren bireylerde naif bireylere kıyasla daha yüksek antikor yanıtı sağladığı gösterilmiştii ${ }^{25}$.

Aşı çalışmalarının büyük çoğunluğu, nötralizan antikorları indükleme stratejisine dayanmaktadır. SARS-CoV-2'ye özgül nötralize edici antikorların gösterilmesi için canlı virüs partiküllerinin kullanımına dayalı plak redüksiyon nötralizasyon ve mikronötralizasyon testleri virolojik referans yöntemlerdir ${ }^{8}$. Bu testlerdeki, 5-7 günlük inkübasyon süresi ve biyogüvenlik düzeyi 3 laboratuvar gerekliliği rutin kullanımlarını büyük ölçüde sınırlandırmaktadır ${ }^{11,26}$. Bu nedenle donanımlı bir altyapı gerektirmeyen, yüksek verimliliğe sahip ve nötralizasyon testlerine oranla daha ucuz olan serolojik SARS-CoV-2 testlerinin, nötralizan antikor varlığını göstermede belirteç olarak kullanılması alternatif olabilir ${ }^{11}$. 
Serolojik testlerde, $\mathrm{N}$ proteini, S proteini, S proteininin S1 alt ünitesi ve RBD olmak üzere farklı antijenik hedefler kullanılarak $\operatorname{lgM}, \operatorname{lgG}, \operatorname{lgA}$ yanıtı gösterilebilir ${ }^{27}$. Bir metaanalizde $^{28}$ nötralizan antikorların, total virüse özgü lgG ile büyük oranda, anti-S IgG ve anti RBD lgG pozitifliği ile özgül olarak korele olduğu gösterilmiştir. Buna ek olarak, Patel ve arkadaşlarının enzim immünoassay prensibine dayanan, S1 ve $\mathrm{N}$ antijenlerini hedef alan beş farklı ticari testin performansını karşılaştırdıkları çalışmada ${ }^{29}$; antikor yanıtları ile nötralizan antikor titreleri arasında en yüksek korelasyon \%97.8-100 oranlarıla bizim çalışmamızda kullandığımız S1 proteinini hedef alan Euroimmun kiti ile tespit edilmiştir. Ayrıca $N$ proteininin, zarf yapısının içerisinde yer almasından dolayı bu antijene karşı oluşan antikorların SARS-CoV-2 üzerinde nötralize edici bir etkisi olmadığı bildirilmiştir. Bu nedenle, nötralizasyon testlerinin yapılamadığı durumlarda SARS-CoV-2 S1 antijeni ve RBD gibi yüzey yapılarını hedef alan serolojik testlerin tercih edilmesi önerilmektedir.

Bu çalışmada COVID-19 enfeksiyonu geçirmeyen sağlık çalışanlarında; yaş, cinsiyet, VKi ve sigara kullanımı ile aşı sonrası humoral immün yanıt arasında istatistiksel olarak anlamlı farklar olduğu tespit edilmiştir. mRNA temelli aşının kullanıldığı ve 514 sağlık çalışanının dahil edildiği bir çalışmada ${ }^{16}$, antikor yanıtı ile yaş arasında istatistiksel olarak anlamlı bir ilişki olduğu ve en yüksek antikor düzeylerinin, çalışmamıza benzer biçimde, 30 yaş altı grupta saptandığı bildirilmiştir. mRNA aşısının kullanıldığı bir diğer çalışmada, humoral immün yanıtın istatistiksel olarak anlamlı biçimde kadınlarda, 37 yaş altında ve VKi $<20 \mathrm{~kg} / \mathrm{m}^{2}$ olan bireylerde daha yüksek olduğu saptanmıştır ${ }^{30}$. Çalışmamızda da naif bireylerde kadın cinsiyeti ve VKi'nin $<20 \mathrm{~kg} / \mathrm{m}^{2}$ olması, daha yüksek antikor düzeyleri ile ilişkili bulunmuştur (sırasıyla $\mathrm{p}=0.005$ ve $\mathrm{p}=0.008$ ). Buna ek olarak sigara kullanımının inaktif SARS-CoV-2 aşısına gelişen antikor yanıtını olumsuz etkilediği ve sigara kullanan bireylerin daha düşük antikor yanıtı verdiği saptanmış ancak sigara kullanımının SARS-CoV-2 aşı yanıtıyla ilişkisini gösteren başka bir çalışmaya rastlanmamıştır. SARS-CoV-2 aşı çalışmalarında; farklı prensiplere dayanan aşılara karşı antikor yanıtında yaş, ırk, etnik köken, cinsiyet, VKi ve sigara içme durumu gibi çeşitli faktörlerin etkisinin araştırılması gerekmektedir.

İnaktif SARS-CoV-2 aşısının 18-59 ve $\geq 60$ yaş gruplarında yapılan iki faz çalışmasında en sık görülen yan etkinin enjeksiyon bölgesinde ağrı olduğu ve ciddi bir yan etki gözlenmediği bildirilmiştir ${ }^{10,12}$. Bu çalışmada da benzer şekilde en sık, kas eklem ağrısı, baş ağrısı ve enjeksiyon bölgesinde ağrı gibi hafif ve kendini sınırlayan yan etkiler saptanmış olup, aşılanan bireylerin \%70'inden fazlasında ASiE gözlenmemiştir. mRNA temelli SARS-CoV-2 aşılarında ise, inaktif SARS-CoV-2 aşılarından farklı olarak en sık tespit edilen ASiÉler arasında ateş yüksekliğinin yer aldığı, ikinci doz sonrasında ASiE sıklığının daha yüksek olduğu ve COVID-19 enfeksiyonu geçiren bireylerde daha ciddi ASiE saptandığı bildirilmektedir ${ }^{22,31,32}$. Bizim çalışmamızda ise inaktif SARS-CoV-2 aşısının ikinci dozu sonrasında ya da COVID-19 enfeksiyonu geçirmiş bireylerde ASiE sıklığı ve ciddiyeti arasında istatistiksel olarak anlamlı bir artış gözlenmemiştir.

Bu çalışmanın en önemli kısıtııı̆ı, aşılanan bireylerin aşı uygulaması öncesi SARS-CoV-2 antikor düzeylerinin belirlenmemiş olmasıdır. Ancak RT-PCR pozitifliği ile COVID-19 enfeksiyonu tanısı almış bireylerde ilk doz aşı uygulamasından 28 gün sonra saptanan yük- 
sek anti-S1 lgG düzeyleri, sekonder immün yanıtla açıklanabilecek biçimde naif bireylerin ayrımını sağlamaktadır.

Bu çalışmada, naif bireylerde 28 gün arayla iki doz uygulanan inaktif SARS-CoV-2 aşısının, nötralizan antikor yanıtı ile korele olduğu bildirilen anti-S1 lgG yanıtını \%98.5 oranında indüklediği ve bu humoral immün yanıtın 30 yaş altı, $\mathrm{VKi}<20 \mathrm{~kg} / \mathrm{m}^{2}$ olan kadınlarda istatistiksel olarak anlamlı biçimde daha yüksek olduğu belirlenmiştir. İnaktif aşı uygulaması sonrasında ciddi olarak sınıflandırılacak bir yan etki saptanmamıştır. COVID-19 enfeksiyonu geçirmiş bireylerde inaktif SARS-CoV-2 aşısının tek doz uygulanması, naif bireylerde iki doz ile ulaşılan antikor düzeylerinin üzerinde bir yanıt sağlamıştır. Fakat COVID-19 enfeksiyonunda; koruma sağlayan antikor düzeyi veya koruyuculuk süresi henüz tam olarak açıklanamamamıştır. Bu nedenle SARS-CoV-2 aşıları ile sağlanan bağışıklığın ne süreyle devam edeceğine dair ileriye dönük çalışmalara gereksinim vardır.

\section{ETIK KURUL ONAYI}

Bu çalışma, TC Sağlık Bakanlığı COVID-19 Bilimsel Araştırma Değerlendirme Komisyonu onayı (Tarih: 12.02.2021 ve Karar No: 2021-02-10T16-23-51) ve Kafkas Üniversitesi Klinik Araştırmalar Etik Kurulu onayı (Tarih: 11.03.2021 ve Karar No: 2021/29) alınarak gerçekleştirildi.

\section{ÇIKAR ÇATIŞMASI}

Yazarlar bu makale ile ilgili herhangi bir çıkar çatışması bildirmemişlerdir.

\section{KAYNAKLAR}

1. Tan W, Zhao X, Ma X, Wang W, NBAU P, Xu W, et al. A novel coronavirus genome identified in a cluster of pneumonia cases-Wuhan, China 2019. China CDC Weekly 2020; 2(4): 61-2.

2. Zhu N, Zhang D, Wang W, Li X, Yang B, Song J, et al. A novel coronavirus from patients with pneumonia in China, 2019. N Engl J Med 2020; 382(8): 727-33.

3. World Health Organization (WHO) (2021). Coronavirus Disease (COVID-19) Situation Report, 2021. Available from: https://www.who.int/publications/m/item/weekly-operational-update-on-covid-19 (Accessed date: 29 September 2021).

4. Poland, GA, Ovsyannikova IG, Kennedy RB. SARS-CoV-2 immunity: review and applications to phase 3 vaccine candidates. Lancet 2020; 396(10262): 1595-606.

5. Ou X, LBAU Y, Lei X, Li P, Mi D, Ren L, et al. Characterization of spike glycoprotein of SARS-CoV-2 on virus entry and its immune cross-reactivity with SARS-CoV. Nat Commun 2020; 11(1): 1-12.

6. Wong SK, Li W, Moore MJ, Choe H, Farzan M. A 193-amino acid fragment of the SARS coronavirus S protein efficiently binds angiotensin-converting enzyme 2. J Biol Chem 2004; 279: 3197-201.

7. Tai W, He L, Zhang X, Pu J, Voronin D, Jiang S, et al. Characterization of the receptor-binding domain (RBD) of 2019 novel coronavirus: implication for development of RBD protein as a viral attachment inhibitor and vaccine. Cell Mol Immunol 2020; 17(6): 613-20.

8. Özçürümez MK, Ambrosch A, Frey O, Haselmann V, Holdenrieder S, Kiehntopf M, et al. SARS-CoV-2 antibody testing-questions to be asked. J Allergy Clin Immunol 2020; 146(1): 35-43.

9. Grigoryan L, Pulendran B. The immunology of SARS-CoV-2 infections and vaccines. Semin Immunol 2020; 50: 101422 . 
10. Zhang Y, Zeng G, Pan H, Li C, Hu Y, Chu K, et al. Safety, tolerability, and immunogenicity of an inactivated SARS-CoV-2 vaccine in healthy adults aged 18-59 years: a randomised, double-blind, placebo-controlled, phase 1/2 clinical trial. Lancet Infect Dis 2021; 21(2): 181-92.

11. Tang MS, Case JB, Franks CE, Chen RE, Anderson NW, Henderson JP, et al. Association between SARS-CoV-2 neutralizing antibodies and commercial serological assays. Clin Chem 2020; 66(12): 1538-47.

12. Wu Z, Hu Y, Xu M, Chen Z, Yang W, Jiang Z, et al. Safety, tolerability, and immunogenicity of an inactivated SARS-CoV-2 vaccine (CoronaVac) in healthy adults aged 60 years and older: a randomised, double-blind, placebo-controlled, phase 1/2 clinical trial. Lancet Infect Dis 2021; 21(6): 803-12.

13. Bueno SM, Abarca K, González PA, Gálvez NMS, Soto JA, Duarte LF, et al. Interim report: Safety and immunogenicity of an inactivated vaccine against SARS-CoV-2 in healthy chilean adults in a phase 3 clinical trial (preprint). Available from: https://www.medrxiv.org/content/10.1101/2021.03.31.21254494v1

14. T.C. Sağlık Bakanlığı COVID-19 Aşısı Bilgilendirme Platformu. Available from: https://covid19asi.saglik. gov.tr/?gclid=EAlalQobChMI_prMh-2j8wIVtIODBx0XGwlzEAAYASAAEgJ-XfD_BwE (Accessed date: 29 September 2021).

15. Perkmann, T, Perkmann-Nagele N, Koller T, Mucher P, Radakovics A, Marculescu R, et al. Anti-Spike protein assays to determine post-vaccination antibody levels: a head-to-head comparison of five quantitative assays (preprint). Available from: https://www.medrxiv.org/content/10.1101/2021.03.05.21252977v1.

16. Jabal, KA, Ben-Amram H, Beiruti K, Batheesh Y, Sussan C, Zarka S, et al. Impact of age, ethnicity, sex and prior infection status on immunogenicity following a single dose of the BNT162b2 mRNA COVID-19 vaccine: real-world evidence from healthcare workers, Israel, December 2020 to January 2021. Euro Surveill 2021; 26(6): 2100096.

17. Jackson LA, Anderson EJ, Rouphael NG, Roberts PC, Makhene M, Coler RN, et al. An mRNA vaccine against SARS-CoV-2-preliminary report. N Engl J Med 2020; 383(20): 1920-31.

18. Jeewandara C, Kamaladasa A, Pushpakumara PD, Jayathilaka D, Sepali I, Danasekara S, et al. Antibody and T-cell responses to a single dose of the AZD1222/Covishield vaccine in previously SARS-CoV-2 infected and naive health care workers in Sri Lanka (preprint). Available from: https://www.medrxiv.org/content/10.11 01/2021.04.09.21255194v1

19. Logunov DY, Dolzhikova IV, Zubkova OV, Tukhvatullin Al, Shcheblyakov DV, Dzharullaeva AS, et al. Safety and immunogenicity of an rAd26 and rAd5 vector-based heterologous prime-boost COVID-19 vaccine in two formulations: two open, non-randomised phase 1/2 studies from Russia. Lancet 2020; 396(10255): 887-97.

20. Xia S, Zhang Y, Wang Y, Wang H, Yang Y, Gao GF, et al. Safety and immunogenicity of an inactivated SARSCoV-2 vaccine, BBIBP-CorV: a randomised, double-blind, placebo-controlled, phase 1/2 trial. Lancet Infect Dis $2021 ; 21(1): 39-51$.

21. Chahla RE, Tomas-Grau RH, Cazorla SI, Ploper D, Pingitore EV, Lopez MA, et al. Past SARS-CoV-2 infection elicits a strong immune response after a single vaccine dose (preprint). Available from: https://www. medrxiv.org/content/10.1101/2021.03.14.21253039v1

22. Krammer F, Srivastava K, Simon V. Robust spike antibody responses and increased reactogenicity in seropositive individuals after a single dose of SARS-CoV-2 mRNA vaccine (preprint). Available from: https:// www.medrxiv.org/content/10.1101/2021.01.29.21250653v1

23. Saadat S, Rikhtegaran-Tehrani Z, Logue J, Newman M, Frieman MB, Harris AD, et al. Single dose vaccination in healthcare workers previously infected with SARS-CoV-2 (preprint). Available from: https://www.medrxiv. org/content/10.1101/2021.01.30.21250843v5

24. Wise J. COVID-19: People who have had infection might only need one dose of mRNA vaccine. BMJ 2021; 372: n308.

25. Yalçın TY, Topçu DI, Doğan Ö, Aydın S, Sarı N, Erol Ç, et al. Immunogenicity after two doses of inactivated virus vaccine in healthcare workers with and without previous COVID-19 infection: Prospective observational study. J Med Virol 2021; 94(1): 279-86. 
26. Weidner L, Gänsdorfer S, Unterweger S, Weseslindtner L, Drexler C, Farcet M, et al. Quantification of SARSCoV-2 antibodies with eight commercially available immunoassays. J Clin Virol 2020; 129: 104540.

27. Chen M, Qin R, Mei J, Yang Z, Wen W, Li J. Clinical applications of detecting IgG, IgM, or IgA antibody for the diagnosis of COVID-19: A meta-analysis and systematic review. Int J Infect Dis 2021;104:415-22.

28. Post N, Eddy D, Huntley C, van Schalkwyk MC, Shrotri M, Leeman D, et al. Antibody response to SARSCoV-2 infection in humans: A systematic review. PloS one 2020; 15(12): e0244126.

29. Patel EU, Bloch EM, Clarke W, Hsieh YH, Boon D, Eby Y, et al. Comparative performance of five commercially available serologic assays to detect antibodies to SARS-CoV-2 and identify individuals with high neutralizing titers. J Clin Microbiol 2021; 59(2): e02257-20.

30. Pellini R, Venuti A, Pimpinelli F, Abril E, Blandino G, Campo F, et al. Obesity may hamper SARS-CoV-2 vaccine immunogenicity (preprint). Available from: https://www.medrxiv.org/content/10.1101/2021.02.24.21251 664v1

31. Polack FP, Thomas SJ, Kitchin N, Absalon J, Gurtman A, Lockhart S, et al. Safety and efficacy of the BNT162b2 mRNA Covid-19 vaccine. N Engl J Med 2020; 383(27): 2603-15.

32. Baden LR, El Sahly HM, Essink B, Kotloff K, Frey S, Novak R, et al. Efficacy and safety of the mRNA-1273 SARSCoV-2 vaccine. N Engl J Med 2021; 384(5): 403-16. 